\title{
Formation of Requirements to the Competency Model for a University Graduate in the Digital Economy
}

\author{
Irina Bagaeva \\ Peter the Great St.Petersburg \\ Polytechnic University; \\ Graduate School of Business and \\ Management \\ St..Petersburg, Russian Federation \\ irinabagaeva1@gmail.com
}

\author{
Anastasiia Levina \\ Peter the Great St.Petersburg \\ Polytechnic University; \\ Graduate School of Business and \\ Management \\ St..Petersburg, Russian Federation \\ alyovina@gmail.com
}

\author{
Olga Voronova \\ Peter the Great St.Petersburg \\ Polytechnic University; \\ Graduate School of Graduate School of \\ Service and Trade \\ St..Petersburg, Russian Federation \\ ilina.olga@list.ru
}

\begin{abstract}
The article considers the issues of formation of requirements to a competency model for university graduates in the digital economy that allow ones to be competitive in the current economic environment. The urgent character of the problem stems from the requirements that are shaped by digitalization processes in the economy. The recent years have witnessed another wave of activity model transformation in education caused by the emergence of cutting-edge digital technologies. Implementation of these technologies could increase company productivity by $40 \%$. In the near future, international competitiveness will be determined by the effective use of digital technologies along with the specialists who possess the required skills and competences. This is particularly relevant for both individual companies and entire countries which form the infrastructure and legal environment for digitalization.
\end{abstract}

Keywords - competencies, digital economy, digital technologies, university graduate

\section{INTRODUCTION}

In present-day conditions, work culture is getting changed together with the increasing role of fundamental education that ensures occupational mobility, willingness to master new technology, in particular the information technology. Currently, there is an increasing demand for previously nonexistent competencies and skiils involving joint work enhanced by technologies that integrate both information and material products, virtual and real products, as well as the objects of augmented reality.

Over a long period of time the wide spread of digital technology has determined economic and social development trends and has repeatedly led to drastic changes in people's lives. Establishment and development of digital economy is one of the priorities for the majority of economic leaders , including the USA, Great Britain, Germany, Japan, etc. These countries are typically characterized by a lengthy period for the implementation of "digital development agenda" as well as by the continuity in priorities - from the development of the basic information-communication infrastructure, up to the formation of coordinated policy and programs to support the comprehensive implementation of digital technologies.
Competencies form the basis of a person's inner wealth in other words, they build up human capital assets. They are shaped, implemented and developed via various types of activities, with economy playing the leading role. The fundamental solution to the issue of ensuring competent workers in terms of digital economy lies in understanding the nature of people's interconnection with digital economic activity. According to Buckminster Fuller "it is necessary to rethink the notion of labor due to the end of the Industrial era" [1]. Attitude to labor underwent fundamental changes during the transition from industrial to post-industrial economy, and later on - to the digital economy. The attitude to labor is determined by the major trends of modern economic development.

Education has become one of the most essential and promising platforms of global competition for economic power and political influence in the XXI century.

In the recent years, Russia has managed to achieve significant results on this arena. Nonetheless, global competition requires solution of very specific tasks in the field of education, in order for Russia to remain a fullfledged, independent and respected member of the international community.

Today, the world has entered the era of accelerating technological changes, so the present day is characterized by drastic transformation of numerous occupations, with many of them becoming obsolete while the new ones emerge. In technologically advanced market segments the lifespan of a profession is already becoming shorter than the lifetime of a professional. At the same time, traditional educational system, aimed at reproducing professionalism, - is rather inertial.

What we need is modern specialists who have profound knowledge of the digital environment, understand how to apply up-to-date technologies in their work and daily life. Today, the basic computer skills are clearly not enough, though they did seem quite outstanding in the 1990s. It is essential to improve the education system so that it could ensure competent workers for the digital economy.

We are now in a serious need for more University graduates with the basic competencies and skills in the digital economy, IT-specialists and other graduates able to use cutting-edge technologies. It is important that people are 
motivated to master new occupations that are in high demand in the digital economy.

\section{LiterATURE REVIEW AND PROBLEM STATEMENT}

The notion of "competence" or "competency" serves as a general term meaning the integral social, personal, and behavioral phenomenon as a result of learning. The terms are used to describe the quality of professional training and skills.

The word "competence" means one's suitability for performing specific work on the legitimate basis. In other words, the term denotes a certain range of professional matters entrusted to a particular person.

For now, there is no single opinion concerning the nature of terms "competence" and "competency". "Competency" is a notion used to describe the final result of learning, while "competence" means "I know how to do", rather than "I know what to do" which is the previously adopted benchmark in education . N.I. Almazova defines "competence" as knowledge and skills in a certain area of human activity. By "competency" the researcher understands an effective application of competences [2].

N. N. Nechaev offers another definition of competency: "profound knowledge in one's area of activity, deep understanding of the purpose and nature of the work performed, its complex interconnections, phenomena and processes, as well as possible means to achieve the intended goals" [3].

In the UNESCO report "Learning: the Treasure Within" competency is defined in a following way: "Entrepreneurs are no longer looking for qualification that they too often associate with the ability to carry out certain tasks. What they are looking for is "competency", by which they mean a mixture of skills characteristic for each individual, which combines qualification in the strict sense, together with social behavior, group work, leadership and risk-taking abilities"[4].

In recent years, scientists have started to consider competence and competency in terms of digital economy.

Key factors able to ensure successful processes of digitalization include sufficient number of highly qualified staff and availability of adequate jobs, as well as training system to provide specialists with competencies for further development and implementation of digital technologies.

Transition to digital economy significantly changes the labor market. Thus, digital skills are becoming more and more important for employers due to the wide spread of information technologies in all aspects of life. In the nearest future the labor market expects to undergo a large-scale transformation of requirements that specialists are supposed to meet. The reason is that many jobs which survived the previous waves of digital technology implementation can be soon automated. Big data analytics is becoming a vital competence that determines the company's competitive advantages in the future. Skills for working with large amounts of structured and unstructured information allow companies to improve the quality of demand forecasting as well as to streamline the processes, etc.

Implementation of digital technologies leads to serious changes in staff requirements, such as:

- dropping demand for jobs related to carrying out formalized repetitive functions;

- reduced life-cycle of jobs caused by rapid technological changes;
- transformation of competence profiles of some staff categories (risk analysts, HR managers, marketing analysts, contact center operators, etc.) due to changes of operational tools;

- new jobs and occupations emerge;

- demands regarding staff flexibility and adaptability increase;

- greater demands requiring "soft skills" or social and emotional intelligence, in other words - the abilities that make up a difference between a human being and a machine;

- growing demand for specialists with "digital dexterity" — the ability and willingness to use new technologies in order to improve business results.

Development of the cutting-edge digital technologies not only imposes new requirements regarding competencies of future specialists, but also needs them to be ready for constant learning and skills update.

According to the research by the NRU Higher School of Economics [5] the most promising highly skilled occupations that the market needs in terms of digitalization include:

IoT architect (Internet of things) - provides network connection to a variety of diverse devices, ensures data transfer and processing in real time, organizes the storage of information in an optimal way, decreases cyber-risks for the system.

Bioinformatics specialist - analyzes experimental medical and biological data, develops and applies computational methods, particularly, to predict the function of genes and encoded proteins, carry out genetic diagnosis, design drugs, construct the models of origin of species.

Data-journalist - creates various reports based on the data, which provides quantitative substantiation to the content and the facts stated in the text, as well as to the author's opinion.

VR-architect - develops technical equipment and software for the virtual reality broadcasting, designs the virtual world and develops interactive storylines.

Voice user interface designer — develops interfaces for voice interaction with digital assistants, chatbots, personal robots, and builds algorithms of AI responses.

Interface designer of IoT - develops interfaces for the IoT systems taking into account the diversity of devices and the whole range of options for managing them.

Data security engineer - ensures confidentiality and encryption, prevents unauthorized access to data both within the company and from the outside.

Robotics engineer - resolves problems concerning control and maintenance of robotic systems at manufacturing sites and in the service industry.

Data researcher - processes and analyzes large amounts of data, detects certain trends, patterns, and develops forecasts in order to solve problems of business and science using statistical analysis and mathematical models.

IT-lawyer - provides legal support of business in the digital economy.

Computer linguist - develops programs and algorithms based on natural language, creates text and speech recognition tools, translation systems, thus, participating in the AI development.

Robotics consultant - specializes in moral, ethical, social and legal aspects of interaction between robots and people, defines the responsibilities of system architects, 
operators and owners regarding the "actions" of machines, rights and freedoms of robotic systems, and observing a robot as a legal entity, etc.

Cyber-prosthetic architect - develops functional artificial devices (cyber-prosthesis) and organs compatible with living tissues.

Neural interfaces architect - develops communication systems aimed at reading brain activity and providing exchange of information between the human brain and external devices (computers, neuroprosthesis, VR-neural helmets, home appliances, etc.).

Specialist in digital logistics - implements innovative solutions concerning optimization resources and added value in digital supply chains.

Tissue engineer - develops and grows living functional tissues or organs outside the body for further transplantation.

Digital marketing expert - promotes products and services via digital channels of interaction with customers, including the Internet, digital television and social media. Marketers use a variety of digital devices (smartphones, game consoles, smart watches, fitbits, etc.).

Digital producer - manages complex multi-platform media projects involving digital means of content production, including mobile applications, multimedia books, video games, on-line courses, Internet series.

Before speaking about competencies required in terms of digital economy, it is important to define what digital economy is as a certain type of economic formation.

International community has not yet developed a comprehensive definition of digital economy. While describing digital economy the majority of foreign sources focus on technology and the associated changes in interactions between economic agents. At the same time, such sources may refer to specific types of technologies or certain forms of changes in economic processes. On the other hand, digital economy is often defined descriptively by the areas of its impact on the economy and social life.

For now, Russian specialists have not agreed on a unified understanding of digital economy. Though, the major existent definitions include the following:

- economy of a new technological generation (Address of the President of the Russian Federation to the Federal Assembly of December 1, 2016);

- economic activity with digital data being the key factor of production;

- processing large amounts of data and analyzing the results in comparison with traditional forms of management can significantly improve efficiency of production, equipment, storage, sale, and delivery of goods and services (Strategy for development of information society of the Russian Federation, 2017-2030) [6]

\section{PROBLEM SOLUTION}

One of the national priorities for the state policy of the Russian Federation is to ensure rapid implementation of digital technologies in the economy and, consequently, in education. Decree of the President of the Russian Federation of May 7, 2018 № 204 "On national goals and strategic objectives of the Russian Federation for the period up to 2024". This statement is supported by the Decree № 204 that sets the following tasks:

- not less than 3 times increase of domestic costs for development of digital economy financed from all sources (by share in GDP) in comparison with 2017.;

- develop stable and secure information and telecommunication infrastructure for high-speed transmission, processing and storage of large amounts of data available to all organizations and households;

- introduce the use of mainly domestic software for state bodies, agencies and local authorities.

Accelerated introduction of digital technologies in the economy and social life is an ambitious goal, which is successfully implemented only in few leading countries. Moreover, it is possible to achieve this goal only if a combination of essential conditions is met.

Firstly, both business and social sphere are supposed to be ready for digital transformation. By this we mean these spheres should have development strategies that entail drastic changes in the way jobs are managed and performed. The reason for this is the planned intensive introduction of digital technologies demanded by organizations and promising the return on investments to the stakeholders.

Secondly, the country has to develop a relatively mature sector of technology supply. This sector does not necessarily have to become an international leader, but should be at least able to transfer, adjust foreign technological solutions and rapidly increase the scope of its actions.

And finally, the demand of population for digital technologies is supposed to grow constantly, because the consumer's needs and capabilities are the ones that ultimately determine the relevant rate of demand for digital technologies from organizations, especially in the $\mathrm{B} 2 \mathrm{C}$.

Digitalization is the reason why technologies become more advanced, thus, making many traditional jobs obscene due to automation of working operations. At the same time, digitalization triggers the emergence of new jobs and boosts the demand for nonalgorithmical work and creativity - socalled "humane in a human".

Digitalization requires development of new competencies in the labor market. Consequently, it entails restructuring of the entire education system. With the development of crossborder education, a highly competitive environment is being created in the fast-growing global educational market, where both providers of educational services coexist: traditional USA, UK, and new -East and South-East Asia, Eastern Europe and the Middle East.

The number of students entering the country's universities after school graduation is growing by $10 \%$ per year and is expected to reach 8 million people by 2020. Many countries, including Russia, have already adopted and are now implementing programs to support the education export. In the nearest future, labor market will experience the increased influence of young workers, mainly the representatives of generation $\mathrm{Z}$ that use digital technologies almost from birth (digital natives), have unlimited access to information, and possess advanced digital competencies. By 2025, the representatives of generation $\mathrm{Z}$ will account for $25 \%$ of total employment in the world [7]. Unlike previous generations that were mostly motivated by career promotion and higher salary, young workers are now encouraged by opportunities 
for personal development, including the non work-related one.

Therefore, universities will have to change educational policy, including the form and methodology of classes, teaching model, and qualification of teaching staff, etc, in order to create conditions that contribute to building competencies for the graduates to meet the requirements of the developing digital economy.

Undoubtedly, the system of training is the main source for the development of digital economy because well-prepared specialists will create and apply algorithms and technologies of digital data processing in various economic sectors, as well as develop high-tech products and services, and introduce innovations [8].

Development of digital economy has resulted in growing social demand for essential transformations within the education system. Previously high-demand jobs are now replaced by the modern ones that require new competencies, such as: skills in digital transformation management, ability to apply digital technologies at manufacturing sites, etc. Thereby, it is necessary to revise current education programs and develop new ones. These changes will be followed by the revision of education standards in all countries. Of course, the requirements for teacher training will subsequently change. Implementation of lifelong learning will surely impose large responsibility on the system of staff improvement and retraining. It is also necessary to train new elite - or highly qualified staff [9]. All the problems enumerated can be resolved by formation of new competence profiles of university graduates.

We fully agree with the article [10], in which authors identify eight competencies that are crucially important for a university graduate in the digital era:

- ability to process large amounts of information and detect the most meaningful fragments;

- ability to structure priorities, understand the patterns of one's own knowledge and skills, and meet one's need for self-development;

- ability to create new markets and developed forecasting skills;

- creativity;

- research competence;

- self-development and flexibility;

- ability to communicate (communicative competence);

- management abilities (managerial competence).

The role of social interactions in the virtual space is now becoming increasingly important. This fact leads to the growing amount of information people receive as well as to the increasing number of business contacts. Therefore, the ability to process big data and quickly navigate the flow of information give professionals an opportunity to choose the right development area and make business decisions.

A specialist not only has to be able to obtain information, but is also expected to filter it properly in accordance with the basic values and priorities of an enterprise. Thus, one of the most important competences of new graduates is the ability to structure priorities, understand the patterns of their own knowledge and skills, as well as meet their need for selfdevelopment.

In their works the researchers G. Hamel and K. Prahalad refer to this concept using the term "intellectual leadership" [11]. The researchers particularly mean a competence that implies the ability to create something new. This competence involves the ability to foresee the course of a situation and find the most effective preventive steps. Analysis of the corporate economy history of the last 20 years, shows that companies which used to develop the skill of intellectual leadership in their employees proved to be the most successful [12]. At present day, technologies advance so rapidly, that forecasting skills as well as the ability to create new markets, are in a very high demand.

Executives of modern corporations believe that development of these skills is one of the top priorities in terms of strategic development. The education system in Russia should first of all develop the willingness to create things in the students. Student's aptitude to conscious activities (desire and abilities) - driven by non-economic interests and aimed at exploring new areas - should be shaped via learning. Hence, as it was once admitted by E. Fromm, it is necessary to build in students the ability to "wonder and puzzle", "focus", understand oneself and develop self-awareness, together with the healthy attitude to conflicts. Based on the research of leading psychologists (D. Bruner, N. Ternstone, M. Smith, etc.), it is possible to suggest the structure of one's willingness to create something new. This system consists of five elements: value-semantic element (understanding creativity as a fundamental motive of life), cognitive element (exploring ideas and concepts of science that were shaped as a result of studying a certain phenomenon), emotional element (positive emotions and feelings associated with the subject of a creative activity and creativity in general), behavioral element (knowledge of how to carry out heuristic activities), reflective element (ability to assess preparation for heuristic activity, degree of compliance of the actions and the final goal) [13]. The Russian education system should provide a digital production engineer with such a value system, that allow one to combine personal aspirations with the interests of society.

We totally agree with the authors about the importance of the above mentioned competence - willingness to create. We certainly believe it should be shaped via the learning process. This competence will solve the following tasks. Firstly, today Russia experiences a shortage of specialists prepared for postindustrial modernization and open to innovation, ready for joint creativity, eager to "step over the horizon", thirsty for knowledge, and able to "act smart". And, secondly, it is necessary to bring up a specialist who is ready to face the unpredictable future, and care for the interests of society, not only not only for one's own needs. This will ensure the effective technological and economic growth of the country, as well as the preservation of its sovereignty under the growing global instability.

I. A. Sokolov, Head of the Institute of Informatics, RAS, draws attention to importance of research competence [14].

Research competence is usually observed as a set of individually processed research knowledge, skills, experience, value system, and behavioral models shaped during the research [15]. Paying due attention to digital economy actually means attention to science in general, as it has already become a digital sector of economy. Participation of scientific organizations in solving the problems of digital transformation in the Russian economy and Russian society is required. In fact, Russia has reached the final stage of digital transformation and we can already admit the existence of dataintensive sciences - sciences based on the intensive use of data. In recent years, all scientific achievements to a 
very large extent have been based on the development of computational methods and digitalization.

When comparing the competences typical for university graduates of the "pre-digital" era, and specialists working in modern conditions, we can see that research competencies providing dynamic development and innovative growth replace competences that create a "comfort zone" and ensure stability of development.

Modern specialists, university graduates in particular, should be ready for lifelong learning. They are also supposed to be able to adapt to the changing conditions of modern life. Today's university graduate should be flexible and easily adjust to changes.

The need to develop innovative business models and relevant business processes creates new requirements for professional skills of innovative projects managers in the workplace and for the corporate culture shaped under their leadership. Knowledges and skills in the field of information and communication technologies and their application models only will not be sufficient to work in the new digital environment. Managers with systemic and creative thinking, as well as with mobility and communication skills will be in a particularly high demand. Therefore, communication skills are an integral part of the modern digital economy.

A number of researchers came to a conclusion industry affiliation is not typical for managers, due to the fact that they in demand and work in all spheres of economy. Therefore, managerial competence is also an integral factor for a specialist in the digital era. Managerial competence involves the following skills:

- time management

- development and management of distributed groups;

- development of practice groups; modernization of online communities;

- formation of personal image;

- setting personal financial trajectories;

- supporting cross-cultural communications;

- work with the image of the future, etc. [16].

It is necessary to add that digital skills have become an integral part of professional skills in education, science and industry. Implementation of breakthrough technological projects in the digital economy creates demand for specialists who possess a whole range of strong, flexible and specific digital competencies, including:

- profound understanding of one's field, as well as knowledge and experience in related fields ("T-shaped specialist");

- awareness about opportunities and potential risks associated with the use of new technologies;

- knowledge of project management methods;

- "digital dexterity";

- knowledge of big data tools and visualization tools;

- understanding the basics of cybersecurity;

- skills required to manage databases;

- systemic thinking;

- emotional intelligence;

- teamwork;

- capacity for lifelong learning;

- ability to solve problems "on a turn-key";

- ability to adjust and work under conditions of uncertainty [5].

\section{DISCUSSION SKILLS}

Development of technology, digital transformation of companies, growth of competition for jobs, and increasing life expectancy make workers change the scope of professional activity several times during their lives, at the same time acquiring new competencies and skills. In order to stay in demand in the labor market a person has to acquire new knowledge faster than ever before. In connection with this approaches to learning are revisedand educational models get transformed. Education faces numerous challenges today, including development of educational content that meets the requirements of a dynamically changing labor market and human needs, as well as reducing costs via the use of innovative technologies [17]. The most valid trends in the education system include:

- lifelong learning;

- omni-learning (learning with the use of all existing communication channels);

- social learning;

- micro-learning;

- adaptive learning;

- neurolearning;

- remote learning;

- mentoring;

- blended learning;

- project-oriented training;

- "self-learning" organizations;

- EdTech-startups, etc.

Thus, as guidelines it is possible to note the demand for formation of these models of competences when developing training programs in universities.

\section{ACKNOWLEDGMENT}

The reported study was funded by RSCF according to the research project № 19-18-00452.

\section{REFERENCES}

[1] Klaus Schwab. Shaping the Fourth Industrial Revolution. - M. 2018. pp.62-63.

[2] Almazova N. I. Cognitive aspects of intercultural competence formation in teaching a foreign language in a non-linguistic University: extended abstract of EdD dissertation. SPb, 2003.

[3] Nechaev N. N. Formation of Communicative Competence as a Condition for the Development of Professional Consciousness // Vestnik URAO. 2002. № 1. P. 3-21.

[4] The materials of studies conducted by the NRU HSE in 2017-2018 are used: Foresight of demand for professions taking into account the prospects of markets development and advanced technologies; Monitoring the behavior of agents of the innovation process; etc.

[5] What is digital economy? Trends, competences, evaluation [Text]: rep. for XX APR. international. science. conf. on Economics and Social Development, Moscow, 9-12 apr. 2019. I. Abdrakhmanova, K. O. Vishnevsky, L. M. Gokhberg et al.; scientific. ed. Gokhberg, M. ; NRU "Higher school of Economics".- M.: Publishing house of Higher School of Economics, 2019. - 82 p.

[6] NRU HSE (2019). Index of Business Digitalization / Press release. Series "Digital economy". 2018. <https://issek. hse.ru/news/244878024.html> (accessed: 26.06.2019).

[7] Russia 2025: Resetting the Talent Balance. <http://drussia.ru/wpcontent/uploads/2017/11/Skills_Outline_web_tcm26175469.pdf> (accessed: 17.06.2019)

[8] RosStat, NRU HSE (2018). Information Society in the Russian Federation. 2018: stat.sbornik.<https://issek.hse.ru/news/234186392 ahhh! html> (accessed: 22.06.2019) 
[9] Iljashenko, O., Bagaeva, I., Levina, A. Strategy for establishment of personnel KPI at health care organization digital transformation (2019) IOP Conference Series: Materials Science and Engineering, 497 (1), № 012029.

[10] Zaychenko, I., Smirnova, A., Kriukova, V. Application of Digital Technologies in Human Resources Management at the Enterprises of Fuel and Energy Complex in the Far North (2019) Advances in Intelligent Systems and Computing, 983, pp. 321-328.

[11] Hamel G., Prahalad K. Competing for the Future. M.: Olimp-Biznes, 2014. $288 \mathrm{p}$.

[12] Pshenichniy S. P., Migukina N. E., Fatkhullin, A. R. Development of Human Capital as the Basis of Competitive Advantage: Challenges for Russian Companies// Economic Sciences. 2016. №. 12. P. 44-47.

[13] Kozlov, A., Teslya, A. Human factors for development of corporate internal social investments Portfolio (2017) 498, pp. 751-758.
[14] Digital agenda: Challenges and Legislative Solutions. Joint meeting of the Presidium of the Scientific Expert Council under the Chairman of the Federation Council and the Board of the Integration club under the Chairman of the Federation Council // Analytical Bulletin. 2018. №1 (690). 126 p.

[15] Koshkina E.G. Research Competence: the Issue of its Formation in the Framework of Project and Research Activities in and out the University // KANT №1 (26). March. 2018

[16] Atlas of Emerging Jobs. M.: AIS, Skolkovo, 2015. 288 p.

[17] Bagaeva, I., Iliashenko, O., Borremans, A. Theoretical and methodological aspects of the competition approach to the evaluation of the organization's personnel // MATEC Web of Conferences. Vol. 193. EDP Sciences, 2018. 